\title{
The truth about going home
}

Cite as: CMAJ 2019 August 12;191:E896-7. doi: 10.1503/cmaj.190424

CMAJ Podcasts: audio reading at https://soundcloud.com/cmajpodcasts/190424-enc

$\mathrm{T}$

oday she's a state. We've spent all day in clinic topping her up with blood products and narcotics. It's Friday, and we're trying to mend her well enough to last through the weekend. Everything is done, her line is locked, and her mom is packing up. I stop by her room, to review the plan we've made for the next couple of days. But before I can start talking to her mom, I am pinned to the wall by a 9-year-old's stare.

"Do you think it's a good idea for me to go home?" she asks me. Her tone suggests that there's an obvious answer, that it's dumb for her even to have to ask. The question is asked differently by her eyes, which are wide and aware. Aware of the possibilities of a wrong answer. I ask if she's anxious about going home, she says that she is, and we agree that she'll stay in hospital. I don't expect that she'll get out again.

Once she's in her room on the ward, I take her mom aside. We talk about what's coming. And about what's to be avoided, chest compressions and endotracheal tubes. When we get back to the room, she sees that her mom's kind face is ruddied from crying, and asks why. I tell some hasty half-truth that she sees right through. She sizes me up a moment, considering whether to call me out on it. She doesn't.

That night is rough. We're trying to stay on top of her pain with oral meds, holding on to the hope of being able to get her out of hospital. But by the morning it's clear that that's not going to work. Later, a few hours into a hydromorphone infusion, she's comfortable. Comfortable enough, at least.

Comfortable enough to say to me, "I think I might be dying. Is that possible?" I say that it is possible, and when she asks when, I tell her that I don't know. Then her nurse and I stand silently by the foot

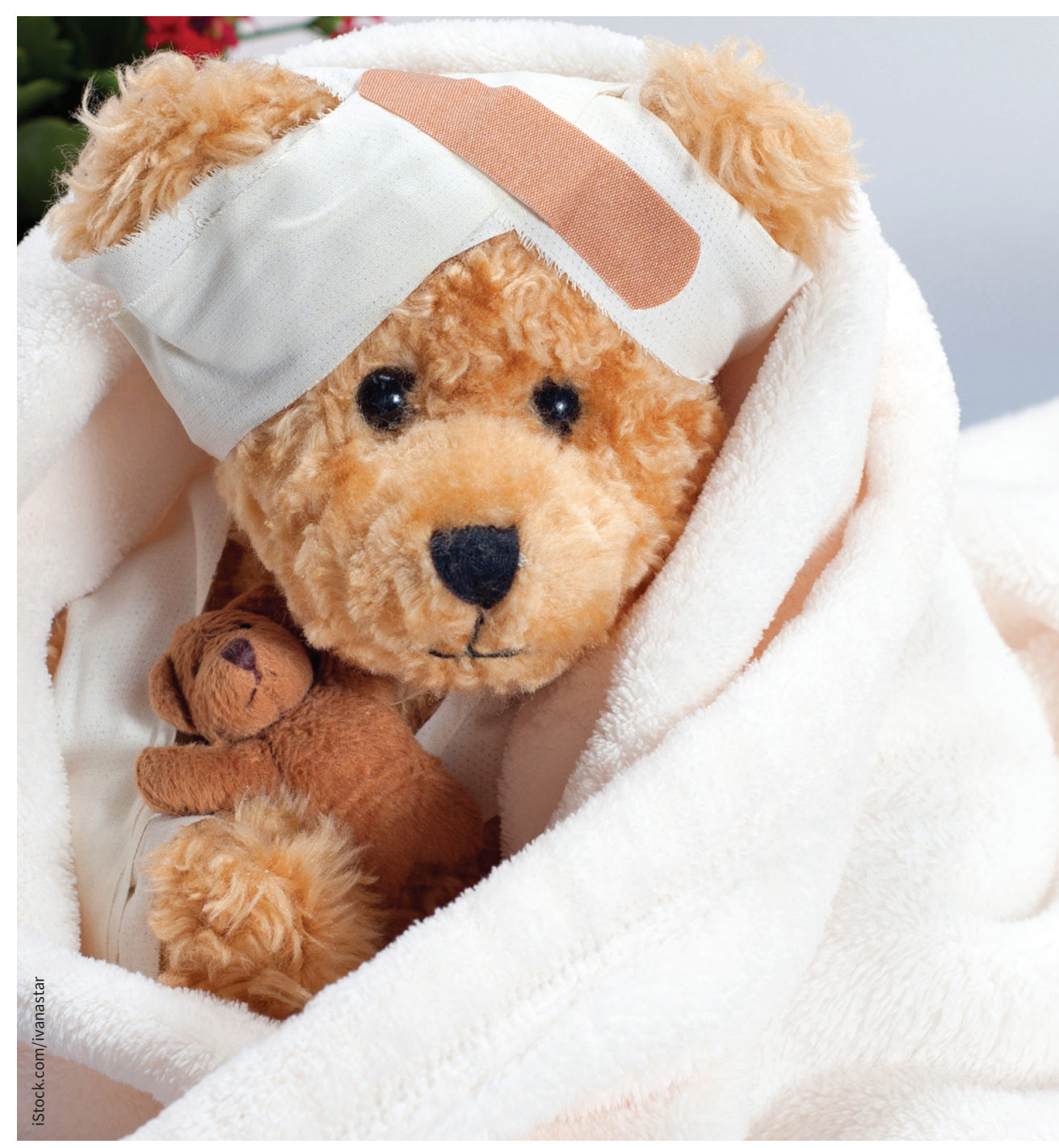

of her bed and listen while she talks to her mom about dying, about loss and leaving, about what comes after. She's never known her dad, who died before she was born, and she talks about meeting him.

She dies a few days later. The ward becomes a crowd of family and friends who've come to see her off, of nurses who've stayed past the ends of their shifts.
I complete her death certificate. The last thing l'll ever do for her is paperwork.

And even though she's gone on paper, she's not gone. I keep hearing her. "Do you think it's a good idea for me to go home?" The skeptical apex that her tone reaches with that "you" echoes in my head.

So does my response, one not said aloud: "Well, now I don't." 
It wouldn't have occurred to me on my own that she didn't want to go home. l'd been so used to seeing her rush out the door as soon as we were done with her. Throwing tantrums, sometimes, when she was made to wait longer than she liked before she could go. Even when she was stuck in hospital, she rarely acted like a patient. She'd always been doing something. Some game or a craft. Once, she ran a hospital for her stuffed animals, using supplies she'd pilfered from the nurses.

"Do you think it's a good idea for me to go home?" She'd never said something like that, not in the six years that I'd known her. What did it take for her to ask that? How scared must she have been? And, of all the people that she saw that day, why did she ask me? Was I just the first person she saw when the prospect of leaving for home became imminent and real? Did she know that I was a sucker for her bittersweet brilliance, that I always hated telling her things she didn't want to hear? Did she trust that l'd tell her the truth?

Was that it? Maybe that was it. Maybe she trusted that I would let her say that she was scared to go home. A day later, she trusted me to tell her that she was dying, so that she could talk to her mom about it.

She trusted that I would understand that it was time.

A few weeks before she died, she had a CT scan. Sliced up like a lemon, she seemed mostly made of cancer. Her lungs looked like a finger painting gone awry. How was she even breathing anymore?
The scan couldn't see that it wasn't yet time, that she still had life in her.

Life that was dwindling, but not gone. Life that she didn't let go of easily. She held on until her fundraiser. And then she held on a little bit longer until her birthday. She squeezed them hard, those days that she stole away from the disease, wrung every drop from them. And then it was time to go.

Do / think it's a good idea for you to go home, my love? Well, now I do.

\section{Paul Moorehead MD}

Janeway Children's Health and Rehabilitation Centre, St. John's, NL

This article has been peer reviewed.

This is a true story. The patient's mother has given her consent for this story to be told. 